\title{
Islands of islands: responses to the centre-periphery fractal model in East Futuna (Wallis and Futuna) and the Belep Islands (New Caledonia)
}

\author{
Adriano Favole \\ University of Turin \\ adriano.favole@unito.it \\ Lara Giordana \\ University of Turin \\ laragiordana@libero.it
}

\begin{abstract}
Starting from two case studies, the Belep Islands (New Caledonia) and Futuna (Wallis and Futuna), this essay presents the hypothesis that colonial and post-colonial dynamics tend to reproduce, as in fractals, the centre-periphery model. In the 'Francophone Pacific' inter-island relationships have historically been created in which the peripheral islands of islands claim their autonomy and, at times, their total independence from the central island. This is the case for Futuna, a peripheral Polynesian island that claims autonomy from Wallis. It is also the case for Belep, in the extreme north of New Caledonia, which suffers from persistent marginality with regard to the Grande Terre. Decolonisation of Futuna and Belep seems possible at the cost of dismantling the centre-periphery fractal model. These islands of islands show us how the reticular model, the enhancement of relationships and reciprocity, and the recovery of their complexity are a possible way out of colonialism.
\end{abstract}

Keywords: archipelagos, centre-periphery, East Futuna, New Caledonia, non-self-governing islands, Oceania

https://doi.org/10.24043/isj.42

(C) 2018 - Institute of Island Studies, University of Prince Edward Island, Canada.

\section{An anthropology of European overseas islands and territories?}

Drawing upon the 'island sovereignty' approach recently proposed by Gerard Prinsen and Séverine Blaise (2017), the present article develops a critique of the centre-periphery fractal model for non-self-governing islands. We understand non-self-governing islands as island and archipelagic territories that are geographically and culturally distant from their metropoles and connected to them by persistent relations imposed on them during imperial colonial times. Our approach echoes Prinsen and Blaise $(2017$, p. 57) in showing that the "islands are not rejecting change: they are rather active in changing that relationship [with the colonial metropole] and they are quite successful in doing so on their own terms." The processes leading to autonomy that we will here discuss are of an active, creative character and model new political and social forms (Favole, 2010).

Our article seeks specifically to underline that even within certain non-self-governing islands and archipelagos, there are islands, such as Futuna and Belep, that are actively negotiating relations with their central island (Wallis and Grande Terre respectively), seen locally as a centre from which to take distance. These are thus islands of islands, aspiring to 
shed the condition of being a hyper-periphery, being able to choose their own relations in autonomy, be it with other islands, other territories, or mainlands. The result, as in the case of Futuna, is a revindication of the peripheral island's autonomy from the central island and the maintenance, creation, or strengthening of a strong connection to the (distant) metropole.

Prinsen and Blaise (2017) set forth five mechanisms as typical characteristics of 'islandian sovereignty': (1) islands vote 'no' in independence referendums; (2) islands continuously negotiate constitutional exceptions; (3) islands get away with bending their metropoles' law or regulations; (4) islands manage public budgets whose shortfall in domestic revenues are complemented by significant financial transfers from the metropole; (5) islands can sign international treaties or agreements beneficial to them but uncomfortable for their metropole and/contrary to its interests. To these, we wish to add a sixth, the coherence of which must be verified through further comparative surveys. What we suggest is (6) the existence or aspiration to create reticular or archipelagic systems through the creation of migrant communities and through the activation of exchange networks that include other islands or areas, which can be near or not so near.

Our approach underlines the importance of local forms of leadership and socio-political organisation. As cultural anthropologists, we agree with Zachary Androus and Neyooxet Greymorning's (2016, p. 447) critique of sub-national island jurisdiction (SNIJ) literature that focuses "on economic factors to the exclusion of social, cultural and political aspects." In the Belep Islands, for example, we are dealing with a chefferie (chiefdom) founded in the middle of the 16th century. During the 19th century, this was transformed in accordance with the will of one of its teamaa (chief), with the influence of Catholic missionaries and under colonial administration. Restructured again in 2005, when the 21st teamaa was installed, it mirrors the present-day needs of Belema society, reintroducing complex ritual and political connections within and without the Belep Islands. The creativity that can be seen in the polyarchy of Futuna results from the island's position between two ancient Polynesian chiefdoms (still vibrant today), a Catholic mission, and recent French institutions. At the same time, the 'gift' and 'redistribution' economy has given these islands a creative form of local welfare state (Favole, 2008) in which the persistent subsistence economy based on horticulture coexists with the transfer of conspicuous funds from the metropole, initiating new 'articulations' (Clifford, 2001). We believe that the way in which local socio-political dynamics shape global and international currents that pass through these islands is of utmost importance. Our experience with participant observation and long-term and repeated fieldwork has led to us acknowledging the complexity of each individual case, which highlights the risk of using 'universal' economic and political indicators without a continuous and attentive consideration of local contexts. 'Deep knowledge' and 'thick description' of local cultures (Geertz, 1973) are necessary to "create the conditions for a symmetrical anthropology and to make possible the idea of knowledge that is both situated and shared" (Saillant et al., 2001, p. 27).

Within this theoretical and ethnographical framework, we find it particularly interesting that Futuna, Belep, and other non-self-governing islands are part of the so-called 'Overseas Europe', namely those islands and territories linked to individual continental European states, which are now (in EU bureaucratic lexicon) known as Overseas Countries and Territories (OCTs) and Outermost Regions (ORs). Over the past decades, these islands and territories have experienced influences not only from their respective metropoles but also from processes of European integration and dis-integration. The present paper in fact belongs to a wider research project concerning intercultural coexistence and statutory changes in European overseas territories, funded by the Department of Culture, Politics and Society at the University of Turin.

Starting from our lengthy field research on 'Francophone Oceania' (Futuna and New Caledonia) and more recent research carried out by Adriano Favole on Réunion Island, our theoretical and ethnographic perspectives now tend towards the development of a 
comparative anthropological approach to the European 'overseas countries'. The notion of 'overseas' is obviously quite problematic and loaded with a colonial burden: apart from its institutional meaning in the ambit of the individual national sovereignties and the EU, it includes a number of islands and territories that are of heterogeneous ethno-cultural composition, are located in diverse regions, and have had divergent colonial and postcolonial experiences. Nonetheless, we feel that it is precisely the variety of the experiences of interethnic conflict and coexistence that make overseas territories an important area of study, offering a set of ethnographic examples useful for developing a discourse on the pluralism of European citizenship.

To simplify, we could say that, viewed from these peripheral islands of Europe, the notion of 'overseas' appears highly ambivalent, ethnocentric, ambiguous, and colonial. The prefix 'over-' in itself sounds 'remote', 'peripheral', if not 'exotic'. Yet it is true that during some historical periods there was a certain convergence between these heterogeneous areas. We refer, for example, to the considerable resonance of the nationalist uprisings of New Caledonia during the 1980s (Ghisoni et al., 1988), to the influence of the créolité ideology in the Caribbean and the Indian Ocean in the 1970s (Bernabé et al., 1989), and to the movements that have characterised the history of many islands, such as the strong presence of the community of Wallis and Futuna in New Caledonia and the tense relationship with local Kanak communities. The current exposure of OCTs and ORs to European integration policies is a further and unprecedented trait-d'union between the overseas territories, the effects of which have thus far been understudied (Adler-Nissen \& Gad, 2013). Based on the model Wouter Veenendaal (2015) proposes for the Caribbean region, we feel it important to develop a comparative analysis of overseas Europe, relative not only to the political dynamics of European nations such as the United Kingdom, France, the Netherlands, Spain, and Portugal but also to the unprecedented relationship with Brussels and EU institutions.

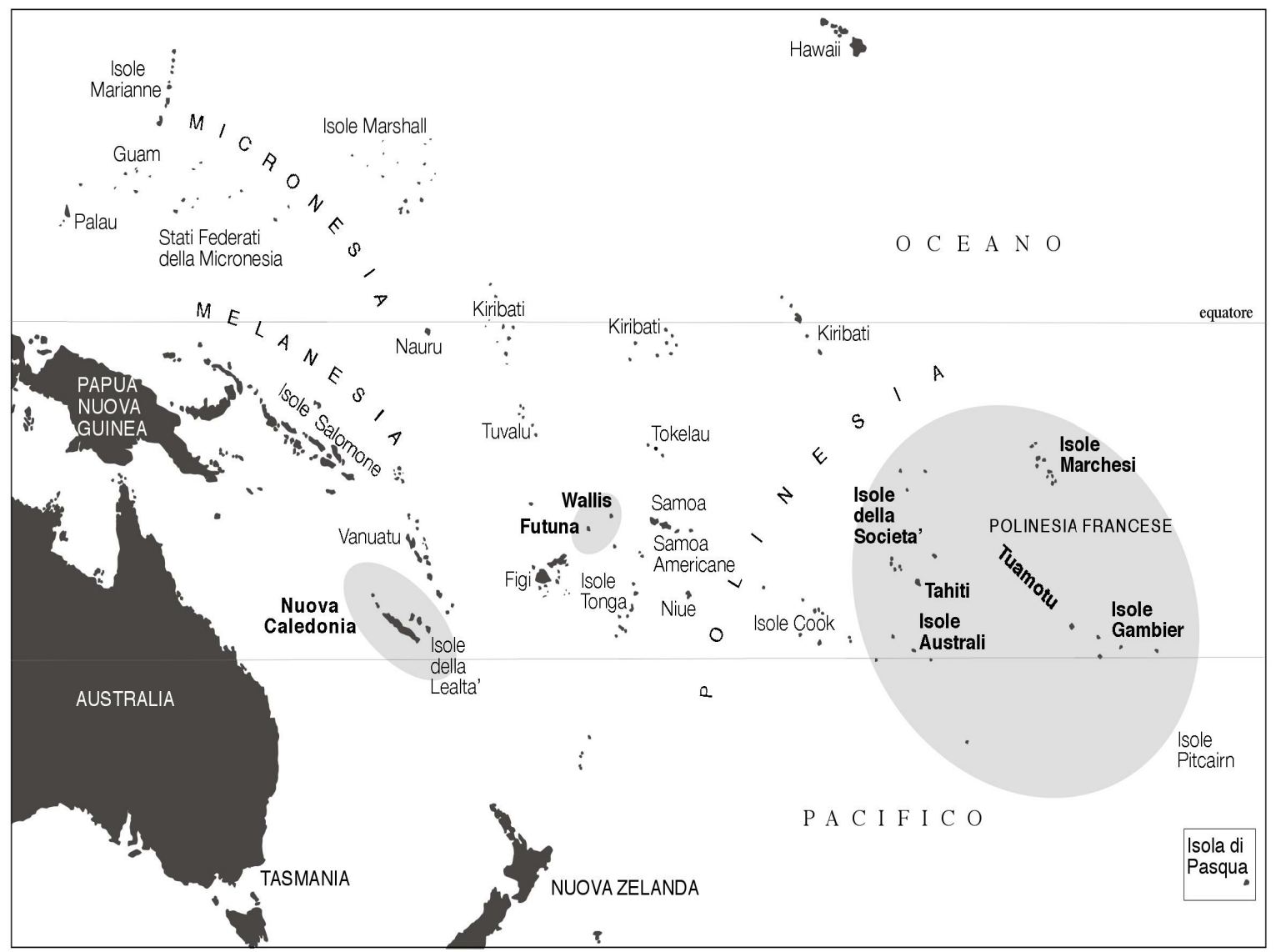

Figure 1: Map of French-speaking Oceania. (C) Adriano Favole, 2010) 


\section{Futuna: a hyper-periphery of Wallis}

Colonial and, more recently, post-colonial politics imposed a 'fractal model' upon islands' political and social organisation, one based on a centre-periphery axis. By 'fractal model', we refer to the replication, at different scales, of the same centre-periphery model of dependence that created actual islands-of-islands in many overseas territories. Today, some of these islandsof-islands are seeking to interrupt these dynamics, claiming autonomy from their central islands. Although we focus on the cases of Futuna and Belep, similar circumstances apply or have applied in recent history to many non-self-governing islands and small island states (e.g. Mayotte and Réunion, Mauritius and Rodriguez, St. Marteen and Curaçao). We take our point of departure from an event that Adriano Favole had the opportunity to investigate in 2006, when the two chiefdoms on the island of Futuna officially asked the French authorities for the constitution of a sub-prefecture.

Futuna is an island in Western Polynesia which, together with Wallis ('Uvea), form the Collectivité d'outre-mer (COM) of Wallis and Futuna (an OCT in EU terminology). Futuna currently has a population of approximately 3600 (INSEE, 2013): in the last ten years, there has been a considerable drop (18\%) in the island's population due to a low birth rate and an intense migratory movement above all towards the Melanesian archipelago of New Caledonia. In 2009, over 20,000 natives of Wallis and Futuna were estimated to be living in New Caledonia, amounting to $8 \%$ of New Caledonia's population. Inhabited around 2700 years ago by an Austronesian-speaking people who made Lapita pottery, Futuna was 'discovered' by Dutch explorers in 1616. A stable European presence was only established in 1837, when Catholic missionaries from the Society of Mary (the Marist Brothers) arrived on the island: this event created the link between Wallis and Futuna (Angleviel, 1994). Quite by chance, the French missionaries settled on both islands, which soon became a French and Catholic enclave in a predominantly Anglophone and Protestant region (Tonga, Samoa, Fiji). A French protectorate from 1887 onwards, Futuna became part of the French overseas territories in 1961, following a referendum in which the local population voted by a large majority (more than 99\%) for annexation by France (Roux, 1995). The Wallis and Futuna's political status has undergone no major changes since, unlike two other OCTs in the Pacific, New Caledonia and French Polynesia, which have acquired progressively more significant forms of autonomy (Lotti, 2010).

From a political standpoint, Futuna is an island in which traditional institutions (two chefferies à titre, the chiefdoms of Sigave and Alo) coexist alongside French-style political institutions, resulting in a polyarchy characterised by a plurality of leaders and power centres (Favole, 2007). The two local chiefdoms (pule'aga sau in Futunan) are confederations of chiefs (aliki), divided into village chiefs (aliki pule kolo) and district chiefs (aliki lasi): the king (Sau) is the supreme authority, not in the sense of holding oligarchic and pyramidal power but as the 'symbol' of the chiefdom and the trait-d'union between the various leaders (Favole, 2000). The spatial extension of Futuna's two chiefdoms, each with their own Sau, coincide with the administrative districts created by the French and with the two Parishes set up by the Church. The two Sau are members of the Territorial Council. The supreme administrative authority of the territory is the Prefect (Futuna is the only OCT to have maintained this colonial-era post), who nominates his Delegate to Futuna. The Territorial Council is comprised of the Prefect, the Prefect's Delegate, the three Sau (the two kings of Futuna and the Lavelua of Wallis), and three members nominated by the Prefect. The Territory also has an Assembly consisting of 20 elected councillors (known as les élus), of whom thirteen are from Wallis and seven from Futuna (four from Alo and three from Sigave). Futuna is among the Polynesian islands to have maintained a traditional system of land management (Favole, 2014; Panoff, 1970): there is still no land register resembling that in Western countries. 
Before the arrival of missionaries and before falling under French influence, Futuna maintained relations with Samoa, which is traditionally regarded as the place of origin of Futuna's first Sau, who introduced the concept of 'royalty' to the island (Burrows, 1936). Some families of chiefs say they come from Tuvalu, others from Tokelau, and yet others from Wallis. According to some elders who Adriano Favole was able to interview in the mid-1990s, in ancient times the people of Futuna often went to fish at Cikobia, an island in Fiji. It is said that a migratory wave from Cikobia led to the inhabitation of Tikopia, a Polynesian enclave in the Solomon Islands studied by the famous ethnologist Sir Raymond Firth. The peoples of Futuna and Tikopia speak two very similar Polynesian dialects, and reconstructions of Patrick Kirch (1994) suggest that they at one time shared an analogous ritual agricultural calendar.

Although it is now difficult to estimate the frequency of the journeys back and forth and the intercultural contacts, we can be certain that Futuna was by no means isolated in the past. In 1996, when Adriano Favole undertook his first fieldwork on the island, the Futunans who had just returned from their first participation at the Festival of Pacific Arts (Apia, Samoa) said they were astonished to have 'discovered' an island on which a completely comprehensible language was spoken. As the French presence increased, however, Futuna progressively became peripheral to a new centre, Wallis/'Uvea. The missionaries set up the headquarters of the Diocese and the Bishop's Palace on Wallis. When the Protectorate was founded at the end of the 19th century, Wallis had the right to host a French secular Commissioner, while the delegation to represent the French institutions (custody of the flag, postal service, poll tax collection) was entrusted to the head of the Catholic mission until 1956. With the creation of the Territory of Wallis and Futuna, the centre-periphery model was further strengthened. The Prefect took up residence on Wallis, and all heads of the various services (public works, culture, agriculture) lived on Wallis. Futuna was only home to their 'delegates'. Holding the majority in the Assembly, the island of Wallis claimed most of the funds destined for the territory. The only port capable of receiving large cargo ships is on Wallis, while the small port of Leava on Futuna is closed in rough seas. The international airport at which large planes can land, the bank, the shopping centres, and the car dealers are all based on Wallis. Once linked to Samoa and outside the orbit of the ancient Tongan empire (which conquered Wallis, imposing a member of the Tongan royal family as supreme head), Futuna is now dependent on the 'Tonganised' island of Wallis. Every year, Wallis is the destination for hundreds of Futunan children who, when they have completed their middle school studies, go to the senior high school and sixth form college on the 'rival island' (there are no secondary schools on Futuna).

When returning to Futuna for fieldwork in 2006, Adriano Favole came across a lively political discussion that pervaded many discourses of the traditional chiefs and of the élus (Favole, 2007). During a recent journey to France in which they had met President Jacques Chirac, a delegation of Futunan chiefs had officially asked for the creation of a sub-prefecture on the island, receiving the general approval of the President. It was, according to Favole's interlocutors, a first step towards the creation of the Collectivite d'outre-mer of Futuna. The sub-prefect, unlike the Delegate of the Prefect, would be nominated directly by Paris, without passing through the rival 'centre' of Wallis. The difference may appear subtle, but it would open up a new scenario, in which supreme administrative authority would be disentangled from the rival island. Although this measure, repeatedly announced by the French authorities, would never be put into practice, it is a symbol of the widespread intolerance that the Futunans show towards the people of Wallis. Generally speaking, Futunans desire the subprefecture in order to claim a direct-rather than mediated-bond with France.

In common with many other non-self-governing islands (Princen \& Blaise, 2017), Futuna held a referendum (1959) in which the island (like Wallis) voted by a large majority for full annexation by France and access to French citizenship, thus leaving behind the Protectorship period. Futuna, referring to the second identification criteria by Prinsen and 
Blaise as an 'islandian sovereignty' trait, also negotiated constitutional exceptions when a constitutional change became necessary in order to recognise the status archipelago's three Sau (kings) within the République. Wallis and Futuna also benefit from remarkable exceptions to metropolitan laws, such as the public financing of Catholic schools (to which the state has granted a monopoly for primary education) and denial of genuine religious plurality. In the early 1990s, the two chefferies on Futuna declared the Evangelical religion, introduced to the island by a few Futunans returning from university studies in Lyon, as inadmissible. The traditional chieftains went so far as to dismiss some nurses from the hospital in Kaleveleve who had converted to Evangelicalism. In retaliation, for a number of years, the Evangelicals did not participate in the redistributive ceremonies of the katoaga or drink the traditional Polynesian beverage (kava), which to this day represent important social activities, with the act of sharing being considered a demonstration of loyalty to the traditional leaders.

On Futuna, as in the 'paradigm' explained by Prinsen and Blaise (2017), local authorities are constantly negotiating with the metropole, whose financial transfers constitute the entire budget of an island that produces no goods for export. It must, however, be noted that Futuna's economy is far from passive and entirely dependent. Horticulture (taro, yam, manioc), pig breeding, fishing, the building of traditional homes (fale) with local materials, and other economic activities are flourishing and help guarantee life on the island as well as grant those who return after time away the possibility of satisfying their basic needs. Futuna can in a sense be regarded as following the MIRAB model (Bertram \& Watters, 1985), with overseas 'remittances' possessing a special status in this case due to the importance of relationships of exchange and gift giving between those who live on the island and those who do not. Gifts of money that migrant communities send to inhabitants of Futuna during redistributive ceremonies (kataoga) enter the ample circuits of reciprocity through which the people who live on Futuna guarantee maintenance of the land of extended families (kutuga), to which migrants can later (often at retirement) return.

The traditional authorities and the élus on Futuna have encouraged commercial agreements with the Fiji and New Zealand on a number of occasions: in 2006, for example some Futunans bought cars from New Zealand, refusing to pay the tax that is levied on the introduction of non-French goods. The Delegate of the time contested the purchase on the basis of safety rules that would stop people driving a right wheel drive car on the island. To Prinsen and Blaise's five criteria we would add, in Futuna's case, the contestation of the centre-periphery dynamic that links the island to its 'rival' Wallis. The negotiation of autonomy based on a direct link with Paris is reinforced by the conviction that the large migrant community living in New Caledonia and the growing community of Futunans living in France (above all in Paris and the Côte d'Azur) today form a Futunan 'archipelago' that can offer assistance in the event of natural calamities (earthquakes and cyclones) and help the community that lives permanently on the island. This is in addition to the support Futuna receives from the metropole and the conspicuous funding coming from the EU. The 1959 vote by Futunans to join France was without a doubt prompted in part by the possibility of receiving assistance in post-cyclone periods.

The case of Futuna is symbolic because the fractal centre-periphery model can easily be applied on the micro-level as well. The relationship between the island's two chiefdoms (Sigave and Alo) in fact also reproduces the centre-periphery model. As we will see for Belep, the missionary presence had a strong influence on Futuna's dwelling pattern: the nearby island Alofi lost its population quickly and is today used exclusively for horticulture. The northern coast of Tu'a lost part of its population, too. The population concentrated on the southern coast where the mission's churches and schools were built. The presence of the missionaries led to a stabilisation of the borders between the two parts of the island and the 'doubling' of the royalty (which consisted of the right to nominate a Sau or paramount chief). In fact, ever since the missionaries arrived, Alo and Sigave have been two rival halves, battling furiously 
for the right to nominate the Fakavelikele, the 'title' that designates the supreme position on the island (Favole, 2000). While the first missionary, Pierre Chanel, initially went to live in Alo, it was Sigave that benefitted most from the increasing western presence. The first harbour installation was constructed in Leava, and it was in this village of Sigave that the French delegation established its headquarters when the Territory was constituted. Nowadays, Leava is home to the only hotel on the island, a couple of restaurants, a travel agency, and the port. Some islanders describe Sigave using hegemonic concepts such as the 'modern' and 'developed', as in which, for example, young people can spend the evening at a discotheque. Alo is the 'traditional' and somewhat 'backward' kingdom, where the chiefs forbid restaurants, discotheques, and consumption of alcohol on the weekend. Mass is held at 05:30 at Alo's cathedral but has been moved to more 'modern' hours in Sigave. Overall, Alo is the hyperperiphery of Sigave, of Wallis, of New Caledonia, and of the distant metropole- a sort of island of marginality to the $\mathrm{n}^{\text {th }}$ power!

\section{Belep: a story of isolation}

The Belep Islands are an archipelago of small islands situated in the northwest of New Caledonia. Belep consists of Art Island (Aar), Pott Island (Phwoc), and smaller islets. The Belep Islands represent the extreme northern extension of the Grande Terre (as the central island of this Melanesian archipelago is known) and are the most distant destination from the capital Nouméa, which is about $500 \mathrm{~km}$ away.

There is only one permanently inhabited site in the Belep Islands, where all services are concentrated and where the entire population lives. This is Waala, the village situated in the bay of the same name, on the western coast of Art Island. The village is traversed by a tarmacked road and has a water supply, electricity, and telephone lines. There is the mayor's office, a post office, a doctor's surgery, infant and elementary schools, a football pitch, a volleyball court, two or three shops, a petrol station, the office of the chefferie (chiefdom), and a church. There is a jetty where the catamaran and small merchant ships that link the archipelago with the Grande Terre can moor, and a few kilometres away, there is a small airfield.

The Belep Islands' soil is ferralitic and thus unsuitable for cultivation. The coasts of Art and Pott, the two major islands, are scattered with bays and inlets, called nana pwang in the local language (pulu Belep). In the nana pwang, alluvial deposits enrich the reddish soil, making possible the horticulture that is so important for oceanic peoples (Barrau, 1956; Gourou, 1948; Haudricourt, 1962). In the bays stand the mounds in which the yams (Dioscorea sp.) are grown. The Kanak societies of New Caledonia are described by André Georges Haudricourt as the "civilisations of the yam" (Haudricourt, 1964), which is considered a sacred plant.

The yam drives Belep's agricultural calendar, marking the rhythm of work in the fields, and consequently determining the presence of the Belema people (the inhabitants of the Belep Islands) in the bays. In fact, alongside the fields stand the houses seasonally occupied by families in accordance with the production cycle of the crops. In particular, the bays are inhabited continuously during the holidays after the school year, while for the rest of the year the population remains in Waala village, which in turn empties out during the holidays.

The village was founded more than 150 years ago as a result of the combination of two projects: the political project of Wahoulo Chahup II, an enterprising local chief, and the religious project of three French missionaries from the Society of Mary. In 1855, Wahoulo Chahup II spent a few months at La Conception, a Catholic mission created that same year near Port-de-France, now Nouméa. It was a compulsory staging post for all Marists who arrived from France and for over 20 years La Conception was a 'hatchery' for missionaries and catechists sent to open the majority of the missions in New Caledonia and other French colonies in the Pacific (Brou, 1982). Wahoulo insisted with great determination that a group 
of missionaries accompany him to Aar when he returned at the start of 1856 to become the new teâmaa (Dubois, 1985; Lambert, 1855-1875).

Composed of the word teâ ('the first-born, the chief) and the suffix maa, which indicates 'the group', the term teâmaa is translated into French by the expression of colonial origin grand chef ('big chief'). The chain of command implied by the term grand chef only occasionally characterises the figure of the teâmaa, yet the strengthening of the teâmaa's political authority was partly the work of the colonial system and partly due to the enterprise of a number of chiefs from the north of New Caledonia, including Wahoulo Chahup II himself (Douglas, 1972).

The chief ordered the Belema to convert to Christianity as proof of acceptance of his authority, which he also extended through violence to the island of Phwoc (previously a separate political unit from Aar). The plan for political dominance enacted by Wahoulo and the Marist missionaries required unification of the population within a single central settlement. In fact, at the time, the Belema lived in small communities scattered along the coasts - the same sites where seasonal cultivation is located today.

The bay of Waala, the most sheltered on Aar, was chosen as the site for the mission, and the teâmaa transferred the chiefdom's headquarters (kavebu) there. The teâmaa's political ambitions matched those of the missionaries, who sought to implement a 'reduction' on Aar (Dubois, 1985), in accordance with the population concentration model of the reducciones instituted by the Jesuits centuries earlier in South America, then still considered an exemplar of 'evangelical efficacy' (Laux, 2000). Bringing the Belema together around the mission buildings seemed to be the only way of ensuring that children went to school and that everyone took part in catechism and the liturgy.

The processes of production and distribution of symbolic and material resources were likewise centralised, and the teâmaa's social role and political power were redefined to the detriment of complementary figures, such as those of the kawu pwemwa ('masters of the land'). Wahoulo Chahup II, who took the name of Amabili Wahoulo when baptised, did not hesitate to destroy objects, buildings, cultivations, and entire settlements to overcome resistance to the central settlement. Within a couple of years, all the inhabitants of Aar had abandoned the scattered settlements and moved to Waala.

A few years later, the teâmaa and the missionaries replicated this same population, power, and resource concentration scheme on Phwoc, the northernmost island (Gilibert, 2007). Nevertheless, in 1874, the Poyama were forced to abandon the 'reduction' of Phwoc, and after having suffered from periodic epidemics, the island's inhabitants moved to Waala. A French settler took up residence on Phwoc shortly thereafter, and the Belema lost all rights to the island a few years later. It was only in 2010 that some clans were able to reclaim their lands.

Over the past 150 years, the history of the Belep Islands has been characterised by a dual process: while the creation of the central settlement facilitated internal centralisation, it also produced the progressive marginalisation of the small archipelago relative to the rest of New Caledonia. In effect, all the projects for economic development-those attempted by the missionaries and those of the colonial administration - depended on the disruption of local and regional relationships. The Marist Brothers soon founded a sort of theocracy (Devambez, 1989), which translated into the strict control exercised by the missionaries over interactions with the outside world. They presented themselves as the sole interlocutors of the colonial administration and managed relations with the colonists and with the European merchants and sailors, who were mainly interested in copra and fishing for sea cucumbers. Moreover, the new religious groups redirected the traditional relationships between the Kanak communities of northern New Caledonia (Dubois, 1985), leading to the suspension of political relations, marriages, and rituals with groups that had converted to Protestantism.

The reduction in relationships with the outside world led to an increase in Belep's isolation. On other islands, such as the Polynesian islands-including Wallis and Futuna- 
studied by Claire Laux (2000), insularity initially hindered Catholic missionaries' efforts, but as time passed, the situation was reversed in favour of the creation of 'genuine Catholic theocracies', as some observers designated them, ignoring indigenous agency. In contrast, the opposite occurred in Belep, and the characteristics that had initially contributed to the mission's success ultimately became unfavourable. The low population level, which had halved since the arrival of the missionaries, together with the distance from the Grande Terre and logistic difficulties, forced the Marists to abandon Waala in 1876. Nonetheless, Belep's isolation - precisely what drove the missionaries away-attracted the interest of the colonial administration: like the Isle of Pines at the southern tip of New Caledonia, Belep was so great a distance from the Grande Terre as to be ideal as a prison colony for 'undesirables'.

An initial project to create a prison camp for France's communards (supporters of the Paris Commune) failed swiftly, but the opportunity presented itself once again when the Kanak revolted on the Grande Terre in 1878. Over 300 men, women, and children, especially from the region of Bourail, were deported to Aar and, in part, to Phwoc. Their arrival forced the missionaries to return, not only in an attempt to protect the Belema, now converted to Catholicism, from the dangerous influence of the 'pagan' rebels, but also in the hope of converting the new arrivals by integrating them with the archipelago's existing inhabitants. To this end, the Belema, who had returned to their lands during the missionaries' absence, were once again concentrated in Waala. In 1881, the population, which had suddenly increased, seemed condemned to famine due to the lack of land suitable for cultivation. Two years later, as soon as they were offered the opportunity to leave Belep, the majority of the exiles departed, but those who remained were integrated in the Belema society through adoption and marriage.

In 1892, the island of Aar was requisitioned as the site of a leper colony, destined to house the sick from all over New Caledonia (Devambez, 1989). The Belema strongly opposed the island's evacuation, but their efforts were in vain. The leper colony was established, and the original population was transferred to Balade, where they lived in poverty for seven years (Dubois, 1985). Once again, the distance from the Grande Terre made supplying the island too onerous, and in May 1898, the leper colony was closed. Leprosy spread amongst the Belema, who immediately returned to the island after the hospital's closure.

To return to the fractal model, it may be useful to recall that, at the dawn of its colonial history, New Caledonia itself was a penal colony. When not filled with 'social refuse' rejected by the centre, the colonial administration regarded Belep simply as a collection of islands that should be cleared of its population. The colonial government, like the missionaries on many occasions, repeatedly sought to remove the Belema from the archipelago: it would be more useful and convenient to evacuate these islands than to maintain them since they did not offer sufficient resources for independent development along colonially imagined lines (Devambez, 1989).

This situation was associated with a paradoxical demographic situation. The periods of high mortality, caused by epidemics, were followed by phases of overpopulation, linked to sudden increases in the number of inhabitants. The already scarce agricultural areas were further reduced by the presence of French settlers, making it difficult to feed the population, which although limited, was disproportionate to the yield of an increasingly restricted territory. In fact, it was only in the early 1940s that the Belema began to overcome the cycle of illness and population decline. It was even necessary to repair the schools, to house the increasing number of children, and extend the church, which was finally crowded with worshippers (Dubois, 1985).

The history of reception and exile, complementary dynamics that contributed equally to the evolution of the Kanak societies (Naepels, 2013), continued until recent times. In the 1970s, for example, increasingly bitter conflicts over land rights broke into riots that devastated Waala. About 100 young people left Belep to settle on the Grande Terre, 
particularly in Nouméa. Later, in the 1980s, there was a second wave of violence and another considerable departure, with an even greater number of Belema moving to the suburbs of Nouméa. The exodus from Belep to New Caledonia's main city has increased since 1996. Today, an allotment on the edge of Nouméa is called Les Jardins de Belep (Belep's gardens) and maintains close social, economic, and political relations with the village of Waala. At a ritual level, the centre-periphery logic is reversed, since Waala represents the ritual centre, and Nouméa is the periphery. This becomes evident every time a funeral or wedding is celebrated in Waala: a delegation sets out from Les Jardins de Belep to reach the village and participate through gifts and money gathered by the small community of emigrants.

Belep continues to be considered by its inhabitants, and described from outside, as peripheral, marginalised, and even isolated and backward, above all due to transportation difficulties. Once again, however, this is not for geographical reasons alone but is also a result of relatively recent historical factors.

Many Belema men have worked for long periods on merchant ships and big fishing boats because even today the Belema are considered good navigators and sailors. Previously, first with dugout canoes and later with cutters, propelled by oar and sail, the Belema sailed against the currents to Nouméa or to the atolls of Entrecasteaux, over $100 \mathrm{~km}$ northwest of Phwoc. The men went there, above all in December, to catch sea turtles for ceremonial meals, risking a dangerous journey that was never undertaken by just one boat. These activities involved crossing the Grand Passage and then navigation in the open ocean, without the protection of the coral reef. To return, it was necessary to wait for a favourable wind and hope that there was a sufficient supply of drinking water. The final such expedition to the island of Surprise occurred in 1991. Today, the sailing boats have been replaced by small motor boats, mainly bought by professional fishermen with help from the Northern Province, and a similar journey has become impractical because fuel is too expensive for such a long voyage. Moreover, the possibility of reaching the Grande Terre is enormously limited. Waala and Koumac are linked by plane and catamaran twice a week, but these services are cancelled during bad weather. The only way to move (a few) people and (small quantities of) goods is thus on small fishing boats, which can only make the trip to the Grande Terre at great risk.

'Désenclavement' (opening up) is the keyword of every political speech expressed in Belep or concerning Belep and has quickly entered everyday language. The end of the isolation for which everyone longs refers not only to relationships with the other islands of New Caledonia but also to the interior of the small archipelago. Above all, it involves an attempt to revive ancient connections with ancestral lands, located in the bays of Aar and Phwoc, which were weakened by the creation of the central settlement of Waala.

Collective life in Waala is still organised around the chiefdom and the church: the two institutions that created the village continue to support its cohesion and regularly organise forms of cooperation between groups. The village is also characterised by a dense and lively associative fabric that is undeniably encouraged by proximity. Nevertheless, many Belema feel that this close proximity is excessive, at times unbearable. Both young and old dream of escape from the overcrowded centre and a return to life in their lands of origin, a desire that is fostered by community projects to develop permanent settlements in the cultivated bays (Giordana, 2014a, 2014b).

For many years, Belep was seen as an archipelago lacking resources and with precarious ecological equilibrium, attracting the interest of missionaries, colonial administrators, various merchants, and a few settlers who sought to set up businesses mainly destined to fail due to an insularity that was initially profitable yet increasingly transformed into isolation. The population concentration policy, like all colonial projects in Belep, resulted in a reduction of relationships. This was partly deliberate, a means of distancing the Belema from 'negative' influence and possible interference, but the reduction of relationships was also an undesired effect of the high mortality rate: the number of people was reduced, the groups were reduced, 
the islands were reduced, the places and their meanings were reduced (including ancestors and non-human inhabitants). During the second half of the 19th century, entire clans in Belep disappeared, others were adopted, cultivated lands dwindled, relationships with other societies to the north were devastated, and those with Europeans were limited. Later, recognition of the economic and ecological precariousness and fragility of the islands and their inhabitants led to the abandonment of efforts to 'develop' them.

The missionary and colonial projects failed in their attempts to make Belep selfsufficient; however, the causes of this failure were not insularity and lack of natural resources per se. They were rather the isolation and reduction of the main resource of the Belema: the possibility to access others. These islands could never be self-sufficient because no island or society ever is. Instead, every island is in relation - in interdependence with-other islands, with other lands.

\section{Conclusions: from centre-periphery logic to an archipelago logic}

The islands of Futuna and Belep are similar inasmuch as colonisation transformed them into peripheries, into islands of islands. Futuna and Belep are now using different methods, however, in their efforts to uproot this centre-periphery logic and its dynamics. In Futuna's case, a request for autonomy from the central island Wallis is strongly advanced, with Futunans requesting a direct link with the metropole and the EU. In the case of Belep, the perception of isolation and the desire to escape it leads to an emphasis on reviving the complex relations between islands and their interiors. In both cases, a new configuration is emerging or re-emerging: a reticular archipelagic logic counteracts the fractal and colonial centreperiphery logic. Recent work in island studies has considered archipelagic relationships as an alternative to mainland-centric perspectives (Pugh, 2013; Roberts \& Stephens, 2017; Stratford et al., 2011). Archipelagos are by no means 'natural' things but are products of human agency. The archipelagic logic is creative and expansive, and thanks to this, relationships grow. The islands are then considered to be on the same plane as faraway lands, which can also become integral parts of the archipelago.

Recently, European funds have financed the widening of the runway at Futuna's airport and the installation of solar panels on Alofi, where there is no electrical system and where people care for their crops and gardens. The construction of a port at which ships can find harbour in bad weather is also planned with European funding. Futuna's 'archipelago' now extends to Brussels, New Caledonia (home to a large Futunan community), suburban Paris, and towns on the Côte d'Azur. On Futuna, the relationship with the centre-periphery model calls for high schools on their territory, a hospital where women can give birth safely (most women go to Wallis or Nouméa before giving birth), and direct flights to Fiji (thereby avoiding long and expensive transits to Nouméa, via Wallis before being able to take intercontinental flights).

Joël Bonnemaison (1991, p. 119) has argued that Pacific islanders have overcome the limits of insularity by developing a reticular organisation of space: "The island is inhabitable only to the extent to which it is neither the centre nor the suburb, but the element of a course that 'unites' it with the world." A few years later, Epeli Hau'ofa (1993) suggested looking at Oceania not as "islands in a distant sea" but as a "sea of islands." From such a perspective, every island becomes an expanding archipelago, "growing bigger everyday" through that "world enlargement that is carried out by tens of thousands of ordinary Pacific Islanders right across the ocean" (Hau'ofa, 1993, p. 151).

The words of Bonnemaison recall the chemin (the path), a widely used metaphor for relationships and social organisation amongst the Kanak. New Caledonia is traditionally traversed by chemins that united groups from the Grande Terre with the various other islands 
of the archipelago. Even today the Loyalty Islands, the Isle of Pines, and Belep are linked with one another and with the central island in this manner through strong ritual relationships.

Many aspects of the policies of New Caledonia in recent decades have been characterised by an attempt to disrupt the fractal centre-periphery logic in various areas, internal and external, in order to revive the logic of the chemins and of pluralism. From within, this effort was made in particular through the creation of three administrative provinces, which were instituted following the Matignon Agreements, with a decree dated 24 July 1989. In the Northern Province and Loyalty Islands Province, the majority of the population belongs to the Kanak community. The institution of the three provinces balances the heterogeneous population distribution (concentrated in the south) and the parallel distribution of services, centres of power, and capital, promoting an economic 'rebalancing'. One of the requests from the Kanak community for decolonisation was the creation of a 'second capital', identified as the city of Koné. The recent installation of a mining industry for the extraction of nickel (the country's main natural resource) in the north, on the Koniambo massif, responds to the historical presence of a similar metallurgical plant in the south. This measure also aims to disrupt the logic of the 'centre', of the concentration of wealth and resources in the southern area where Nouméa stands, the 'ville blanche' ('the white city').

In terms of relationships with the outside world, the disruption of the centre-periphery model occurs through the progressive transfer of state competencies from France to New Caledonia, as foreseen by the Nouméa Agreement of 1998. In 2018, there will be a referendum in which New Caledonia's citizens will be called upon to express their opinion regarding the transfer of the competences régaliennes: justice, defence, currency, and foreign affairs. If the response is affirmative, New Caledonia will become a new sovereign state. JeanMarie Tjibaou, a leader of the independence movement, who was assassinated in 1989, insisted on interdependencies as the keystone of island sovereignty in Oceania: "Sovereignty gives us the right and the power to negotiate the interdependencies. For a small country like ours, independence consists of calculating the interdependencies properly" (Tjibaou, 1996, p. 179). It is not by chance that the cultural policies advanced in recent years by the JeanMarie Tjibaou Cultural Centre-which has become a reference point for the entire region of Oceania-insist on reviving relationships at the regional level rather than on Kanak identity perse.

Like Bonnemaison, researchers who are currently working with climate change and environmental disasters increasingly emphasise the importance of networks (Barnett \& Waters, 2016). John Campbell (2009) states that the islands of the Pacific, long considered sites of vulnerability, should instead be recognised as places of resilience. The capacity for 'survival' that these societies have shown, for example by developing specific measures to contain the natural disasters and their effects, are closely linked to relationality: it is relationships that have allowed life on the islands. This is shown by the maintenance of nutritional security through agricultural-ecological diversity (Pollock, 2002), which results in enhanced biodiversity, increased by exchanges between peoples - a biodiversity of plant clones and roots on the move (Haudricourt, 1964; Pollock, 1992). In the words of Campbell (2009, p. 85), "Pacific islands, and their inhabitants, are not essentially or inherently vulnerable. They were traditionally sites of resilience. Colonialism, development, and globalisation have set in place processes by which the resilience has been reduced and exposure increased."

Centre-periphery logic has made the islands of Oceania much more vulnerable. As a result, the decolonisation of Futuna and Belep seems possible through the act of dismantling the centre-periphery fractal model. These islands of islands show us how the reticular model, the enhancement of relationships and reciprocity, and the recovery of their complexity are efficacious against disasters and are a possible way out of colonialism. 


\section{Attributions of authorship}

Although this article is the result of joint conception and work, Adriano Favole authored the first part ('An anthropology of European overseas islands and territories?' and 'Futuna: a hyper-periphery of Wallis'), and Lara Giordana authored the second part ('Belep: a story of isolation' and 'Conclusions: from the centre-periphery model to an archipelago logic').

\section{References}

Adler-Nissen, R., \& Gad, U.P. (Eds.) (2013). European integration and postcolonial sovereignty games: the EU Overseas Countries and Territories. London: Routledge.

Androus, Z., \& Greymorning, N. (2016). Critiquing the SNIJ Hypothesis with Corsica and Hawai'i. Island Studies Journal, 11(2), 447-464.

Angleviel, F. (1994). Les missions à Wallis et Futuna au xixe siècle. Bordeaux: CRET.

Barnett, J., \& Waters, E. (2016). Rethinking the vulnerability of small island states: climate change and development in the Pacific islands. In J. Grugel \& D. Hammett (Eds.) The palgrave handbook of international development (pp. 731-748). London: Palgrave Macmillan.

Barrau, J. (1956). L'agriculture vivrière autochtone de la Nouvelle-Calédonie. Nouméa: Commission du Pacifique Sud.

Bernabé, J., Chamoiseau, P., \& Confiant, R. (1989), Eloge de la créolité, Paris: Gallimard.

Bertram, I.G., \& Watters, R.F. (1985), The MIRAB economy in South Pacific microstates. Pacific Viewpoint, 26(3), 497-519.

Bonnemaison, J. (1991). Vivre dans l'île. Une approche de l'îléité océanienne, L'espace géographique, 2, 119-125.

Brou, B. (1982). Lieux historiques de La Conception, Saint-Louis, Yahoué. Nouméa: Société d'Études historiques de la Nouvelle-Calédonie.

Burrows, E. (1936). Ethnology of Futuna. Honolulu: Bernice P. Bishop Museum Bulletin (no. 138).

Campbell J. (2009). Islandness: vulnerability and resilience in Oceania, Shima, 3(1), 85-97.

Clifford, J. (2001). Indigenous articulations, The Contemporary Pacific, 13(2), 468-490. https://doi.org/10.1353/cp.2001.0046

Devambez, V. (1989). Archipel des Bélep (Nouvelle-Calédonie). Essai de monographie historique (1856-1918). MA thesis in History. Aix-en-Provence: Université Aix-Marseille I.

Douglas, B. (1972). A history of culture contact in North-Eastern New Caledonia, 1774-1870. PhD thesis in History. Canberra: The Australian National University.

Dubois, M.J. (1985). Histoire résumée de Belep (Nouvelle-Calédonie). Nouméa: Société d’Études Historiques de la Nouvelle-Calédonie.

Favole, A. (2014). Terre, politique et parenté à Futuna (Wallis-et-Futuna). In F. Angleviel \& M. Abong (Eds.) La Mélanésie. Actualités et études. Foncier et développement durable (pp. 207-220). Paris: L'Harmattan.

Favole, A. (2010). Oceania. Isole di creatività culturale. Roma-Bari: Laterza.

Favole, A. (2008). Forme e dilemmi del dono a Futuna (Polinesia occidentale). In M. Aria \& F. Dei (Eds.) Culture del dono (pp. . Roma: Meltemi.

Favole, A. (2007). Démocratie et coutume à Futuna, La Ricerca Folklorica, 55, 109-122.

Favole, A. (2000). La royauté oscillante. Ethnographie et histoire de la cérémonie d'investiture du Tu'i Agaifo d'Alo (Futuna), Journal de la Société des Océanistes, 111(2), 195-218. https://doi.org/10.3406/jso.2000.2134

Geertz, C. (1973). The interpretation of cultures. New York: Basic Books.

Ghisoni, D., Iopue W., \& C. Rabinet (Eds.) (1988). Ces iles que l'on dit françaises. Paris: L'Harmattan. 
Gilibert, J. (2007). Un voyage sans retour, de l'Aubrac à la Nouvelle-Calédonie. Journal de Jean Gilibert (1818-1891), missionnaire mariste chez les Kanaks. Suva: CEPAC.

Giordana, L. (2014a). Abitare Belep. Etnografia in un villaggio kanak. Ph.D dissertation in Anthropology. University of Turin.

Giordana, L. (2014b). Waala, l'anomalia di un villaggio kanak (Nuova Caledonia). L'Uomo Società Tradizione Sviluppo, 2, 25-44, http://doi.org/10.7386/79672

Gourou, P. (1948). La civilisation du végétal, Indonesië, 1(5), 385-396.

Haudricourt, A.G. (1964). Nature et culture dans la civilisation de l'igname: l'origine des clones et des clans, L'Homme, 4, 93-104. https://doi.org/10.3406/hom.1964.366613

Haudricourt, A.G. (1962). Domestication des animaux, culture des plantes et traitement d'autrui, L'Homme, 2(1), 39-50. https://doi.org/10.3406/hom.1962.366448

Hau'ofa, E. (1993). Our sea of islands. In V. Naidu, E. Waddell, \& E. Hau'ofa (Eds.) A new Oceania: rediscovering our sea of islands (pp. 2-16). Suva: School of Social and Economic Development, University of the South Pacific.

Kirch, P. (1994). The pre-Christian ritual cycle of Futuna, Western Polynesia, Journal of the Polynesian Society, 103, 255-298.

INSEE (2013). Les populations légales de Wallis et Futuna en 2013, https://www.insee.fr/fr/statistiques/2121453

Lambert, P. (1855-1875). Petit journal, 1855-1875. Typewritten document including Petit journal de France à Bélep, 1855-1859 and Petit journal de 1860-1875. Nouméa: Archives Territoriales.

Laux, C. (2000). Les théocraties missionnaires en Polynésie (Tahiti, Hawaii, Cook, Tonga, Gambier, Wallis et Futuna) au XIXe siècle. Des cités de Dieu dans les Mers du Sud?. Paris: L’Harmattan.

Lotti, A. (2010). Le statut de 1961 à Wallis et Futuna: genèse de trois monarchies républicaines (1961-1991). Paris: L’Harmattan.

Naepels, M. (2013). Conjurer la guerre. Violence et pouvoir à Houaïlou (Nouvelle-Calédonie). Paris: Éditions de l'École des Hautes Études en Sciences Sociale.

Panoff, M. (1970). La terre et l'organisation sociale en Polynésie. Paris: Payot.

Pollock, N.J. (2002). Vegeculture as food security for Pacific communities. In S. Yoshida \& P. Matthews (Eds.) Vegeculture in eastern Asia and Oceania (277-92). Osaka: JCAS Symposium Series 16, National Museum of Ethnology.

Pollock, N.J. (1992). The roots remain: food habits in islands of the central and eastern Pacific since Western contact. Hawai'i: Institute for Polynesian Studies.

Prinsen, G., \& Blaise, S. (2017). An emerging 'Islandian' sovereignty of non-self-governing islands, International Journal, 72(1), 56-78. https://doi.org/10.1177/0020702017693260

Pugh, J. (2013). Island movements: thinking with the archipelago. Island Studies Journal, 8(1), 9-24.

Roberts, B.R., \& Stephens, M.A. (Eds.) (2017). Archipelagic American studies. Durham \& London: Duke University Press. https://doi.org/10.1215/9780822373209

Roux, J.C. (1995). Wallis et Futuna: espaces et temps recomposes. Bordeaux: CRET.

Saillant, F., Kilani, M., \& Graezer Bideau, F. (eds.) (2011). The Lausanne manifesto: for a nonhegemonic anthropology. Montreal: Liber.

Stratford, E., Baldacchino, G., McMahon, E., Farbotko, C., \& Harwood, A. (2011). Envisioning the archipelago. Island Studies Journal, 6(2), 113-130.

Tjibaou, J.M. (1996). La presence kanak. Paris: Odile Jacob.

Veenendaal, W.P. (2015). The Dutch Caribbean municipalities in comparative perspective. Island Studies Journal, 10(1), 15-30. 